\title{
Anti-DNA Antibody Measurement
}

National Cancer Institute

\section{Source}

National Cancer Institute. Anti-DNA Antibody Measurement. NCI Thesaurus. Code C81973.

The determination of the amount of anti-DNA antibodies present in a sample. 